$\mathbb{T}$ periodica polytechnica

Civil Engineering

$53 / 1(2009) 25,33$

doi: 10.3311/pp.ci.2009-1.04

web: http://www.pp.bme.hu/ci

(c) Periodica Polytechnica 2009

RESEARCH ARTICLE

\section{Potential of terrestrial laserscanning in load test measurements of bridges}

\author{
Attila Berényi / Tamás Lovas* / Árpád Barsi* / László Dunai**
}

Received 2008-12-12, accepted 2009-01-23

\begin{abstract}
The state-of-the-art geodetic and remote sensing techniques can prove their potential through particular engineering applications. Besides the traditional surveying terrestrial laserscanning broadens its application field in civil engineering projects. The Department of Photogrammetry and Geoinformatics has long experience in the measurement methods, accuracy analysis and applications of terrestrial laserscanning. This paper deals with the potential of the technology through the examples of load test measurements of Danube bridges. Prior to the particular bridge surveying projects accuracy analysis has been carried out in laboratory measurements, the results validated the accuracy and reliability of the laserscanned data. The paper discusses the complex measurement procedure, the main steps of the data processing and results. Remote sensing can provide data about specific (e.g. with limited accessibility) areas of the structure that cannot be measured with traditional techniques during the short period of the load test measurements. The postprocessing includes comparison analysis using ground-based geodetic measurements (such as high precision leveling) as reference in defining displacements. By computing the accuracy measures of the terrestrial laserscanning the overall technology can be qualified and calibrated.
\end{abstract}

\section{Keywords}

terrestrial laserscanning $\cdot$ load test $\cdot$ displacement measurement $\cdot$ deformation measurement

\section{Attila Berényi}

Department of Photogrammetry and Geoinformatics, BME, 1111 Budapest, Múegyetem rkpt. 3., Hungary

e-mail: attila.berenyi@mail.bme.hu

\section{Tamás Lovas*}

Árpád Barsi*

*Department of Photogrammetry and Geoinformatics, BME, 1111 Budapest, Múegyetem rkpt. 3., Hungary

\section{László Dunai**}

** Department of Structural Engineering, BME, 1111 Budapest, Bertalan Lajos u. 2., Hungary

\section{Introduction}

Terrestrial laserscanning is a state-of-the-art remote sensing technology that can rapidly acquire accurate, three dimensional spatial data. The primary engineering application fields are focusing on architectural surveying, mining volume analysis and gathering data about complex mechanical systems for modeling. This paper discusses the potential of laserscanning in engineering survey i.e. displacement and deformation measurement. The validation of the technological capabilities are investigated and demonstrated by laboratory measurements including comparative analysis. The outdoor potential of laserscanning is shown by two Danube bridge load test measurements.

\section{The technology}

The result of a laserscanning measurement is an accurate $3 \mathrm{D}$ point cloud about the surveyed object. The range of the currently used scanners is from 2 to 800 meters, therefore they can be applied both indoor (e.g. laboratory test of portal frame) and onsite (e.g. load test of a bridge). The concept of laserscanning is based on emitting laser light which reflects from the object. Measuring the traveling time of light, the distance between the scanner and object can be computed, whilst for the accurate point location in space the angle of emission is also recorded. The factory given accuracy ( $\pm 5 \mathrm{~mm}$ in case of the applied scanners) has been validated by the Department of Photogrammetry and Geoinformatics in a joint research project with the Department of Structural Engineering (discussed in Chapter "Laboratory measurements"). If needed, the point cloud can be georeferenced in any kind of coordinate system by ground control points.

\section{Laboratory measurements}

In order to validate the accuracy and the overall capability of the terrestrial laserscanners used in the further measurement campaigns, laboratory measurements have been carried out. To investigate the RMSE (Root Mean Square Error) of the laserscanner ranging, deformation of a steel plate has been measured by laserscanner; as reference, the displacements were measured by high precision digital caliper (Fig. 1). The results validated 


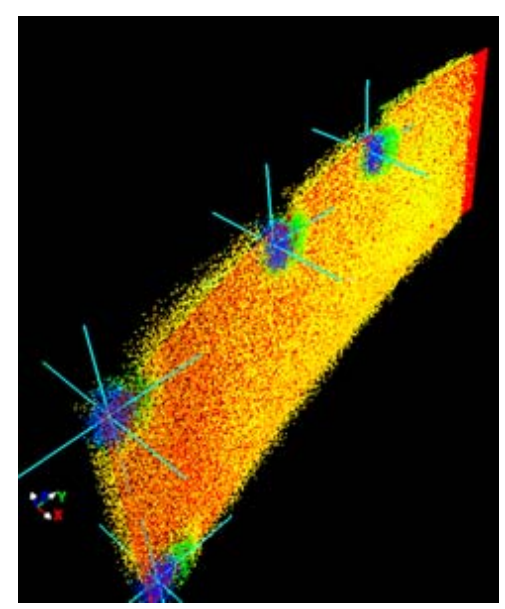

Measurements on point cloud

Fig. 1. Measurements of displacements of steel plate

the factory given $\pm 5 \mathrm{~mm}$ ranging accuracy of the scanner.

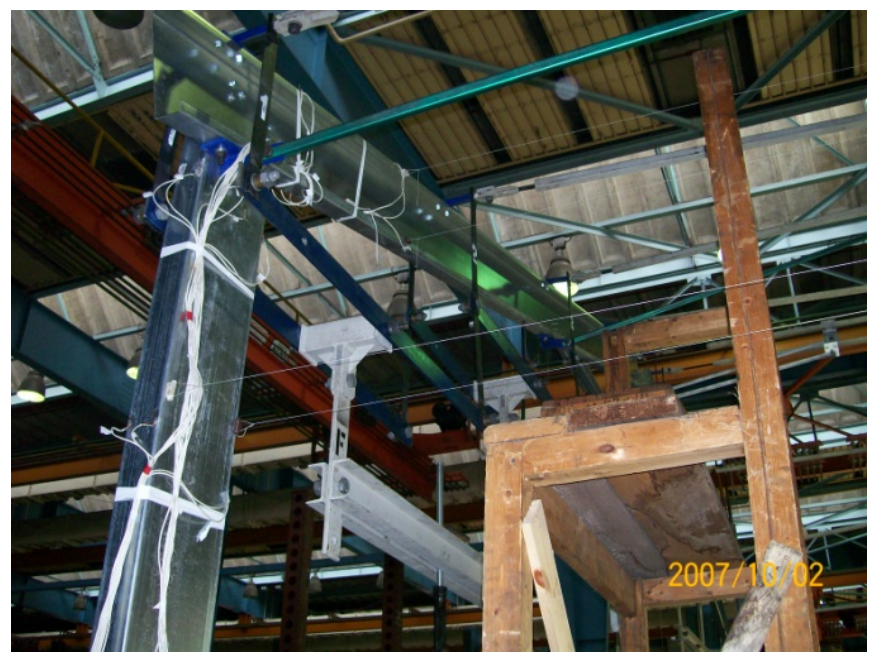

Fig. 2. The portal frame equipped with the sensors

In the second phase of the laboratory tests laserscanning has been carried out in the load test of a Lindab SBS 1 portal frame. The displacements of specified points of the structure have been measured by inductive transducers (Fig. 2) whilst the stresses were measured by strain gauges.

The primary objective was to capture each of the load cases by laserscanner and derive the particular displacements. Additionally, comparing the results with the values provided by the traditional high precision equipments enable to analyze the accuracy of the laserscanning and therefore helps in evaluating its potential for such projects.

Before the test, the unloaded state has been captured as future reference. The load test consisted of separate, static load cases. The load levels were $2.4,4.6,5,9.4,13.7 \mathrm{kN}$ respectively. The 810 minutes static phases enabled the laserscanning of each case.

Comparison of the polygon models is done by built-in algorithms of the processing software (Geomagic 8). The main advantage of this method is that information can be gathered from

\footnotetext{
${ }^{1}$ Small Building Systems
}

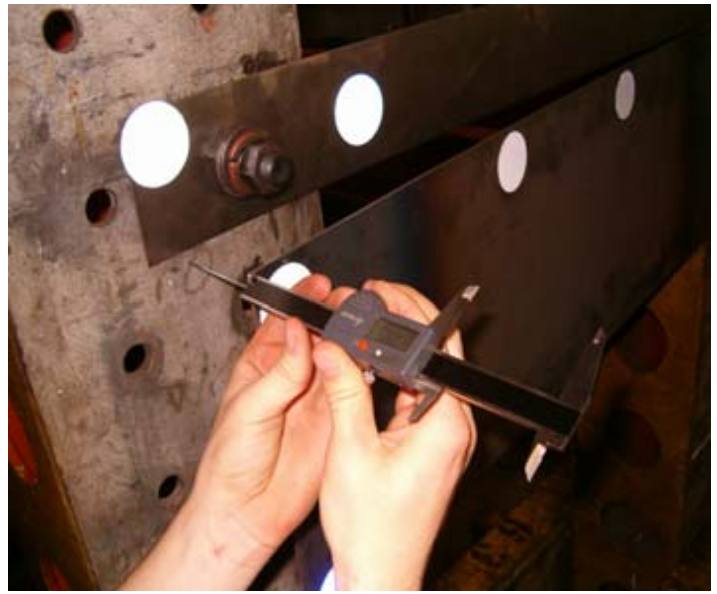

Reference measurements (by caliper)

all (visible part) of the structure, whilst the traditional methods provide data only about the predefined, dedicated points. The resulted figures of each load case provide reasonable information about the deformation of the whole frame, the colors are changing according to the displacement values compared to the reference state (Fig. 3).

Besides comparing the 3D models of each state, measurements directly on the point clouds also have been carried out and validated by the results of the transducers.

\section{Bridge load test I. - Pentele Bridge}

During the load tests of bridges the vertical movements of the bridge deck and the stresses (both in discrete points) are measured. The vertical displacements of the deck (and the main girder) are measured by high-precision leveling, the 3D movements of predefined points of the structure are determined by total stations, whilst the stresses are measured by strain gauges. During the load test a single laserscanner was applied, deployed at the left river bank (Fig. 4).

The Pentele Bridge consists of 3 main parts: 2 parts over the flood plain, and the main part is over the river Danube. The focus of the current study is exclusively on this middle part of the bridge, which is a basket handle type tied arch bridge with a span of $307.8 \mathrm{~m}$ (world record in its category!) and height of 48 $\mathrm{m}$ [9, 10]. The first static load test was performed on the $28^{\text {th }}$ of June, 2007, started at 9 p.m. and lasted 9 hours. In each case the bridge was loaded for 20-30 minutes (minimum time needed for the geodetic measurements), thus that was the time limitation for the laserscanning (Fig. 4).

Since the load cases lasted for only a short period of time and could not be repeated, only one laserscanning station was selected and the scanning resolution was reduced. Therefore the displacements of particular points of two structural parts (the northern arch and the bottom part of the girder) close to the scanner have been obtained. For the scaling, the zero point at the intersection of the arch and the deck (at the left river bank) was selected [8]. 


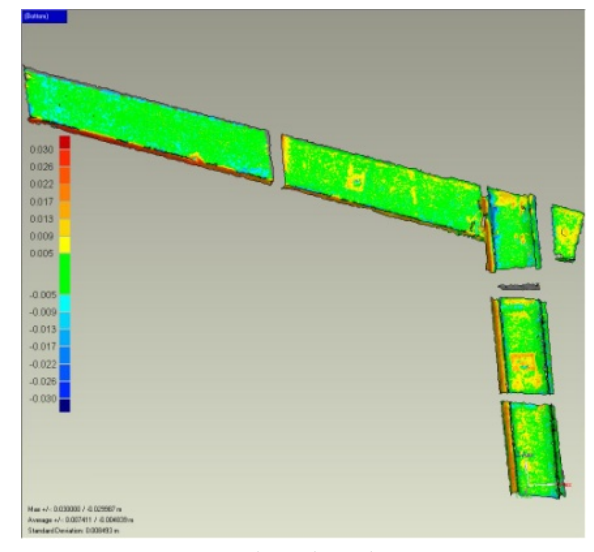

$4 \mathrm{kN}$ load

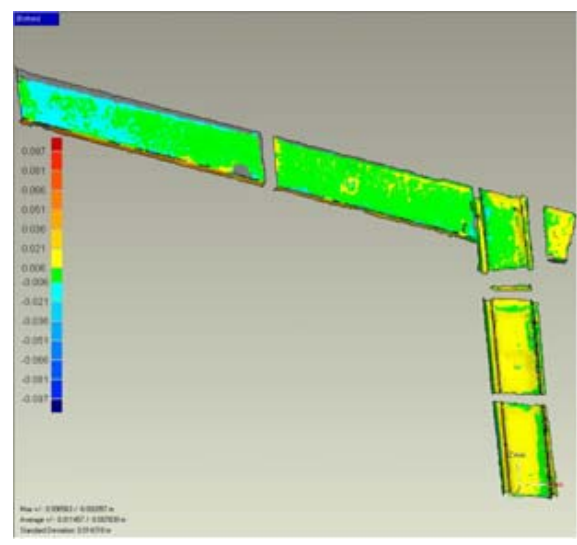

$7 \mathrm{kN}$ load

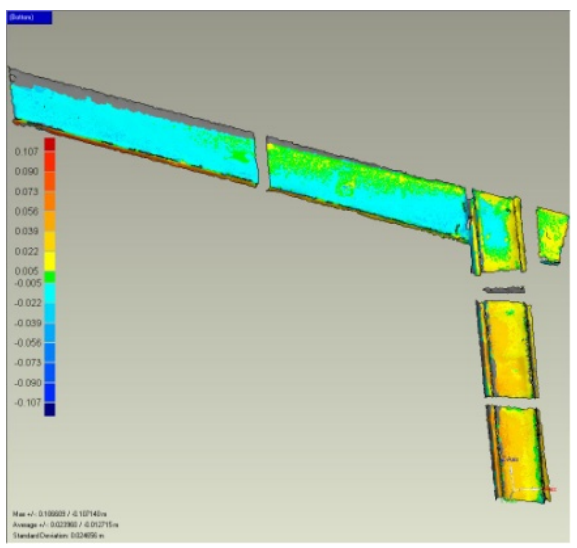

9kN load

Fig. 3. Deformations under different loads

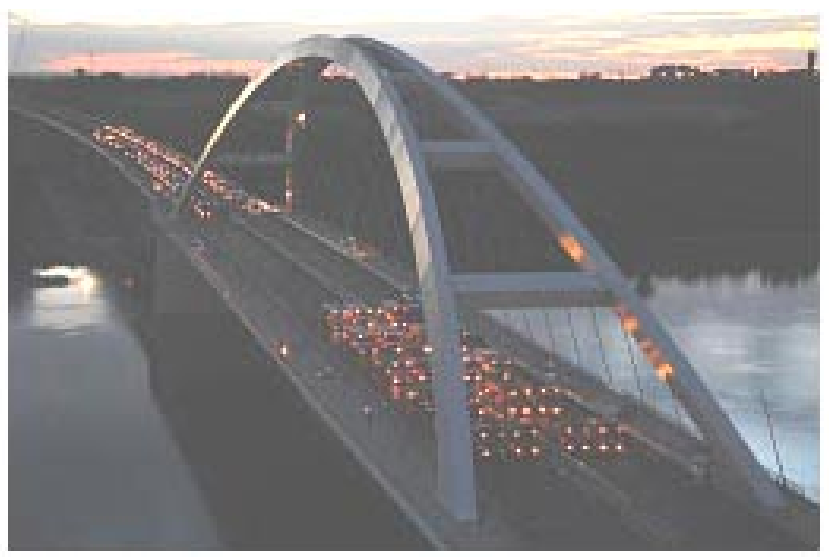

Fig. 4. Load test of the Pentele bridge

The structural displacements derived from the laserscanned data sets are in strong correlation with those obtained from the traditional techniques. The computed maximum vertical displacement is $\sim 35 \mathrm{~cm}$ in both methods in the fourth load case (Fig. 5).

Fig. 5 shows the displacement values obtained from different methods: high-precision leveling (north cables), theoretical (computed/simulated) values and those of derived from laserscanning for both the girder and the arch.

Note that the vertical deflection of the deck is measured directly at the cables whilst the laserscanner captured the edge of the girder, however these structural elements are solidly coupled to each other.

The reason of the oscillation on the curves derived from laserscanned data is the reduced point density; in the resulted data set it is difficult to fit regular edges and planes on the point cloud. After all, the trend of the curves and the displacement values validate the laserscanning measurements.

\section{Bridge load test II. - Megyeri Bridge}

This cable-stayed bridge is the longest river bridge in Hungary (1861 meter), consists of 5 bridges (9 bridge structures). We focused on the largest bridge structure that spans over the Danube with its 591 meter length.

Similarly to the load test of the Pentele Bridge the vertical

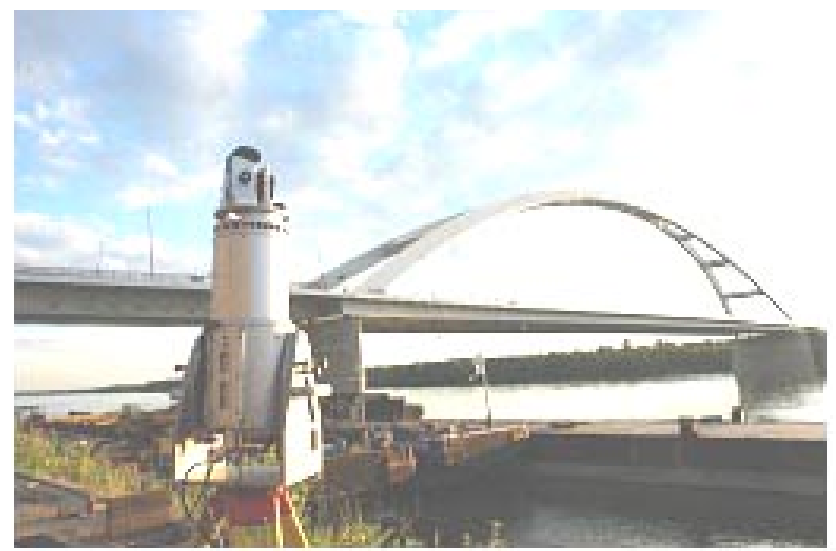

displacements of the deck was measured by high precision leveling, whilst the spatial displacements of dedicated points of the pylons were captured by geodetic total stations.

In this load test two terrestrial laserscanners simultaneously scanned each load case; one (Riegl Z420i) was deployed at the Pest side river bank, the other (Riegl Z390i) was on the side of Szentendrei island in 50 and $35 \mathrm{~m}$ vertical distances from the bridge, respectively (Fig. 6).

The load test was executed on the $23^{\text {rd }}$ of August 2008 and lasted from 7 to $10 \mathrm{pm}$. From the planned 15 load cases only 4 were scanned; laserscanning had to be stopped due to heavy rain.

The particular load cases (Fig. 7):

1 zero measurement, unloaded state,

2 bridge loaded between the pylons and river banks (with 12-12 42-ton trucks),

3 bridge loaded between the pylons (with 24 trucks),

4 measuring the residual deformation, unloaded state.

During the load test the laserscanners operated with the parameters shown in Table 1 The resolution determining the number of points and point density was set by the time required by the high precision leveling in each load case. 


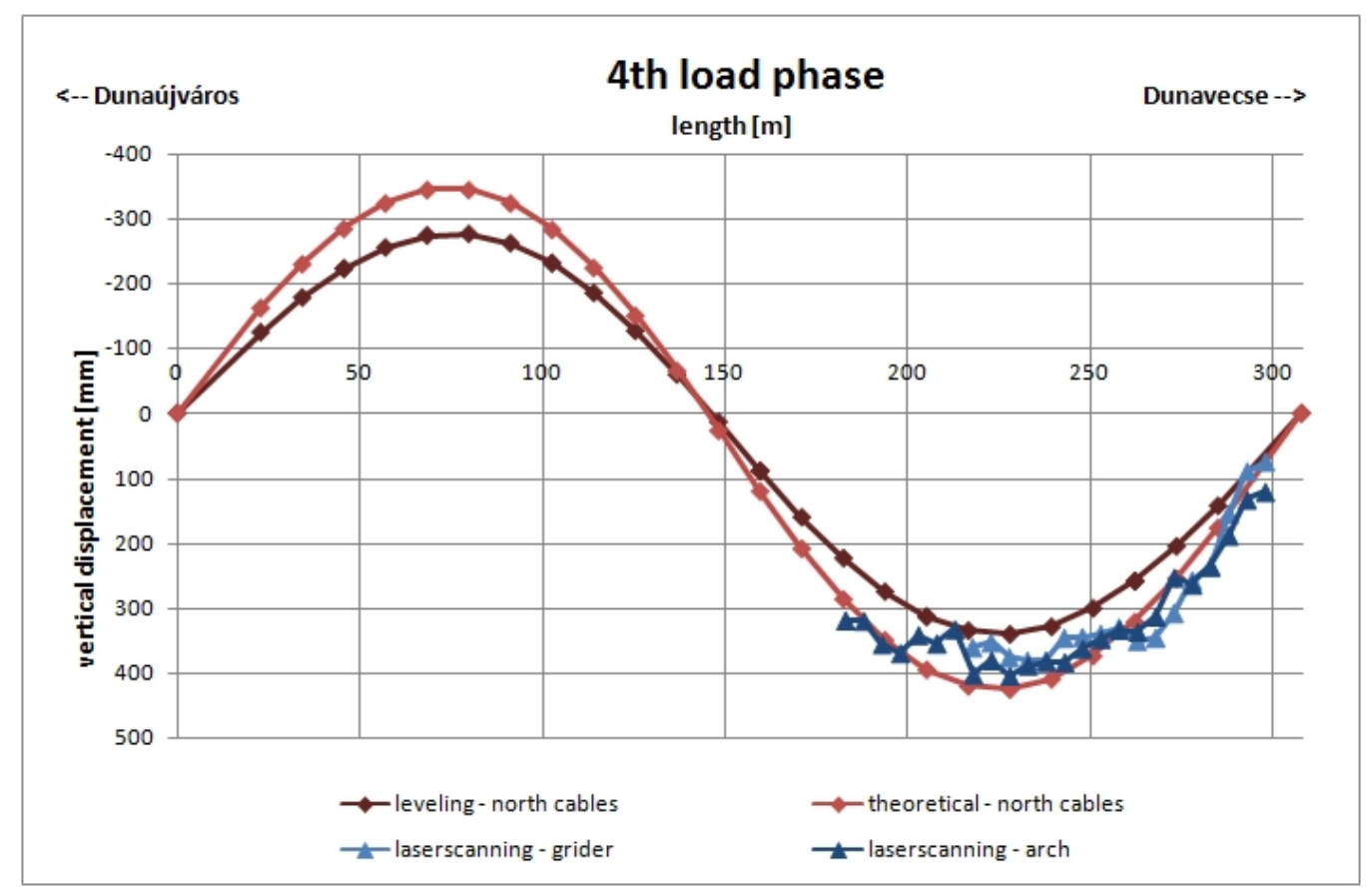

Fig. 5. Displacements of the girder and arch derived by different techniques in the $4^{\text {th }}$ load case (half of the bridge is loaded)

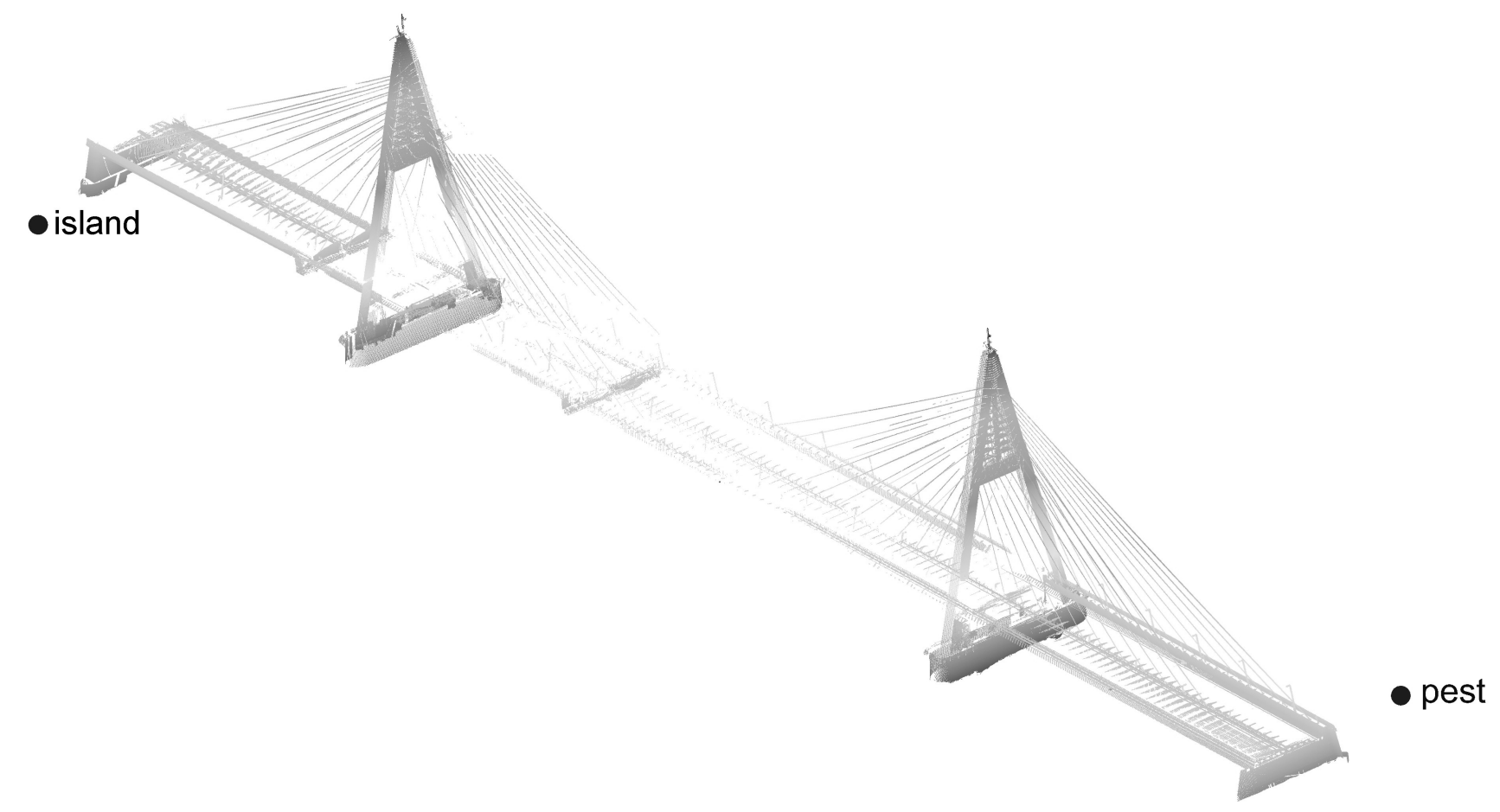

Fig. 6. Point cloud with station locations

The result of laserscanning is a raw point cloud. During the post processing and analysis geometric elements can be fitted and thus the planar or spatial model of the object can be generated. Because of the great number of points and the high point density the visualization of the raw point clouds enables defining basic displacement and deformation tendencies.

In Figs. 8 and 9 the dark points are from the zero measurement (unloaded state) whilst the light points are from the $2^{\text {nd }}$ load case.

The view angle of Fig. 9 enables analyzing the displacements 


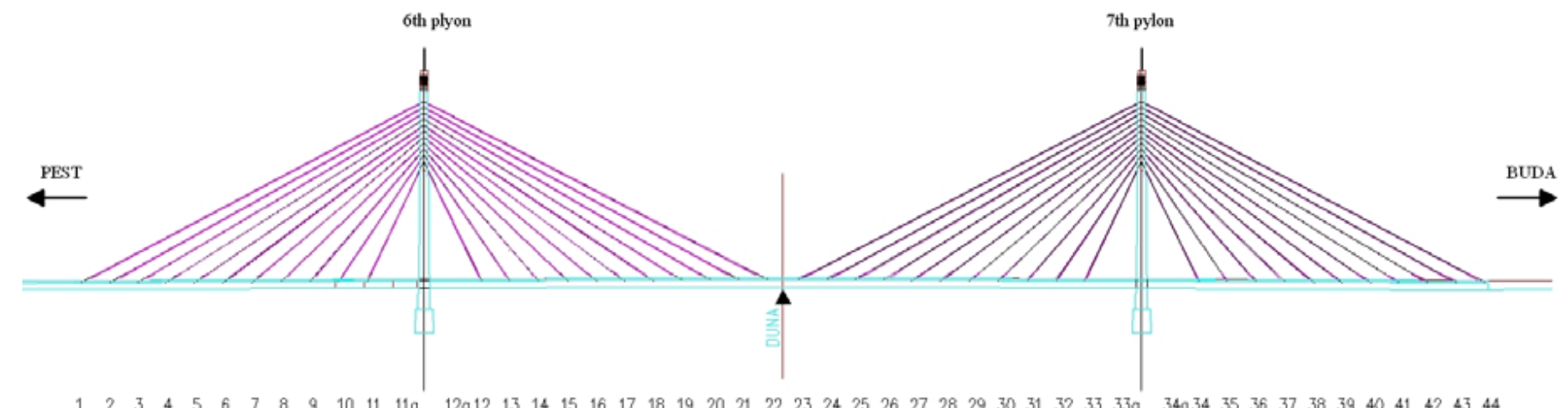

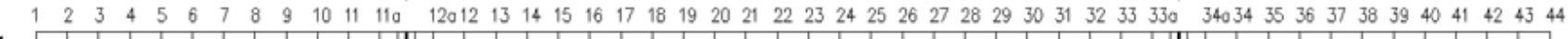

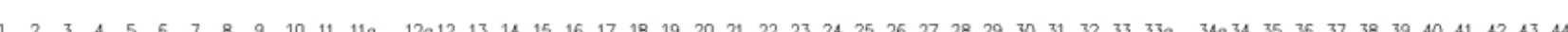

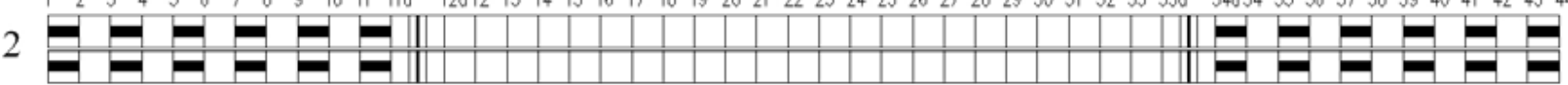

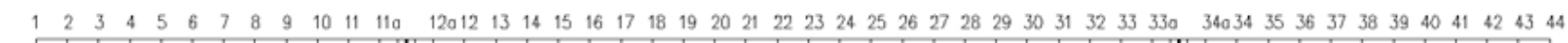

3

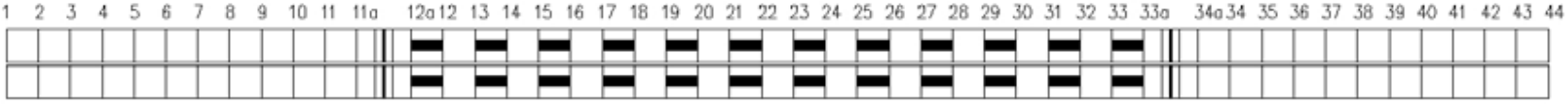

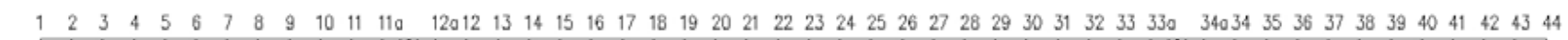

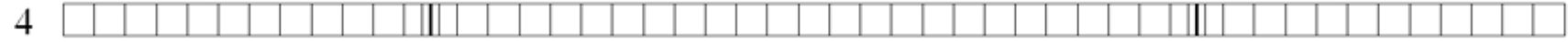

Fig. 7. Laserscanned load cases (1-4)

Tab. 1. Parameters of laserscanning

\begin{tabular}{lcccccc}
\hline & \multicolumn{3}{c}{ Pest (Riegl Z420i) } & \multicolumn{3}{c}{ Island (Riegl Z390i) } \\
\hline scan & meas. time & resolution & no. of points & meas. time & resolution & no. of points \\
\hline overview scan & $1^{\prime} 30^{\prime \prime}$ & $0,20^{\circ}$ & 716604 & $1^{\prime} 29^{\prime \prime}$ & $0,20^{\circ}$ & 713216 \\
\hline detailed scan & $21^{\prime} 41^{\prime \prime}$ & $0,03^{\circ}$ & 5756028 & $21^{\prime} 14^{\prime \prime}$ & $0,03^{\circ}$ & 6407291 \\
\hline
\end{tabular}

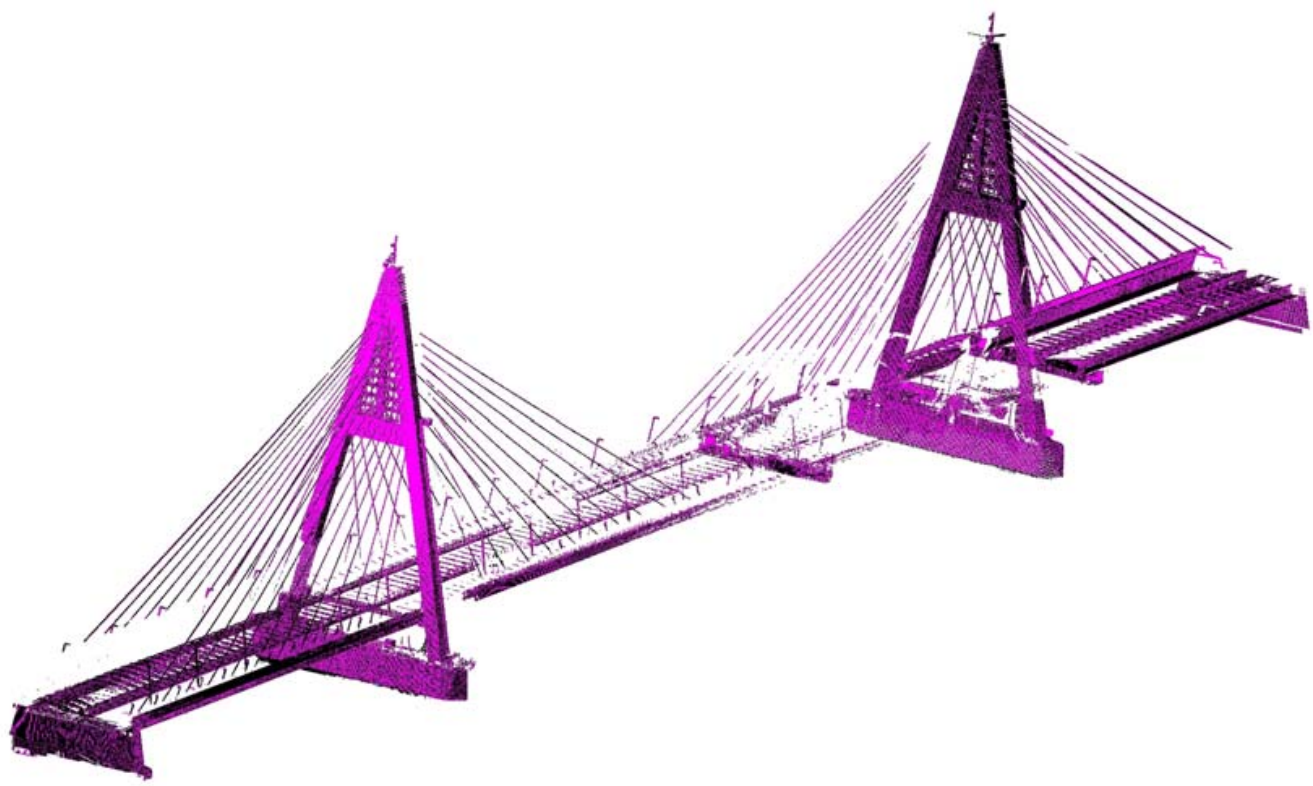

Fig. 8. $2^{\text {nd }}$ load case (dark -unloaded, light - loaded case)

of the pylons, in the $2^{\text {nd }}$ load case the river bank side was loaded, thus the pylons leaned also to the banks (pylons' inner part is dark, outer part is light).

Fig. 9 shows the displacement of the bridge deck, points of $2^{\text {nd }}$ load case are definitely located under the points of the un- loaded state. In the $3^{\text {rd }}$ case the bridge was loaded between the pylons, hence the pylon leaned to each other and the outer parts of the deck moved up.

Exploiting the full potential and high accuracy of the technology, measurements on the point cloud have been carried out. 


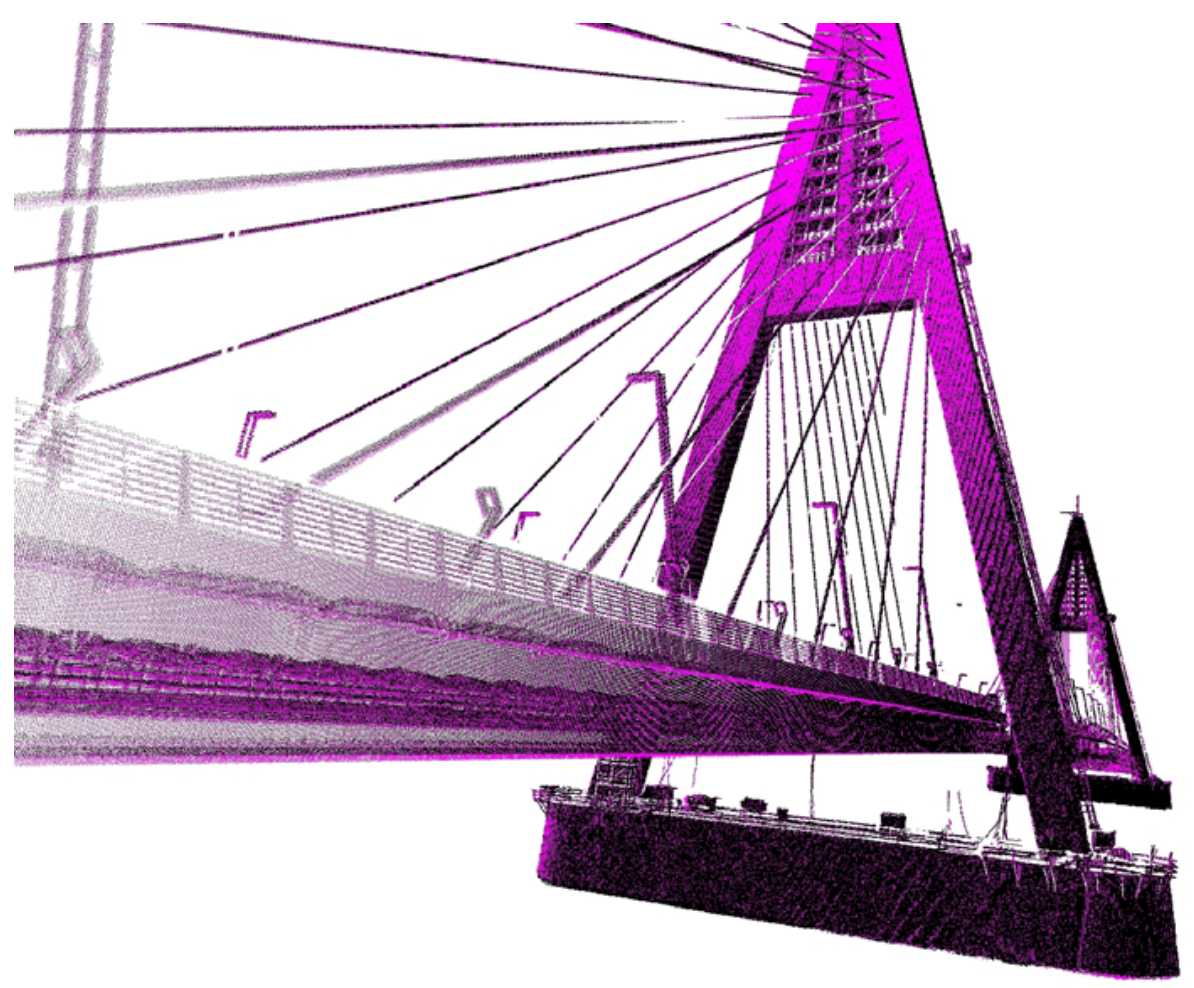

Fig. 9. $2^{\text {nd }}$ load case (dark -unloaded, light - loaded case)

During laserscanning no predefined discrete points but a particular segment of the space including all objects in the range of the scanner is captured. In case of displacement the identification of particular points is extremely difficult. To bypass this problem, planar or spatial objects are fitted to the point cloud (e.g. lines or cylinders to the cables) and the movements and deformations of these elements are investigated.

In the evaluation procedure, the results of the high precision leveling (RMS is less than $1 \mathrm{~mm}$ ) were used as reference. Comparing the laserscanning results to that of the leveling clear correlation can be seen (Fig. 10p. The reasons of the differences in particular points are the following:

- During the leveling, displacements of discrete points, whilst in case of laserscanning the displacements of the fitted lines and arcs are measured.

- In leveling the measurements executed directly on the deck. From the laserscanning stations the lower part of the bridge is seen from below, lines and arcs are fitted onto the cross structures (that, in fact, move together with deck).

- In each load cases the scanner scanned the whole structure in 22 minutes. The bridge slowly moved also during the load cases, that means the laserscanner did not captured a snapshot but the point cloud also "contains" the displacements occurred during the load case.

The effect described in the latter point (i.e. movements during the load case) can be observed in the results: the displacement values are more correlated on the side where the scanning has begun. Considering all the circumstances of the measurement (dark environment, movements during the measurements, the size of displacements etc.), the $\pm 5 \mathrm{~mm}$ accuracy ensured by the laserscanner can be considered as eligible for describing the displacements of the deck. Note that due to the lower point density, the investigation of the middle segment of the bridge is omitted from the evaluation (Fig. 10).

In describing the displacements of the deck laserscanning is not competing with leveling, since more scanners are to be applied simultaneously to avoid the effect of shadowing. In the following certain examples about specific measurements are discussed that emphasize the advantage of laserscanning in comparison with traditional geodetic techniques.

\section{Pylon measurements}

The main advantage of laserscanning can be observed in measurements that cannot be executed by traditional methods or would make the evaluation unaffordable. The displacements of the pylons are measured in discrete points (by special point markers) by geodetic total stations. In contrary, laserscanning provide data about the total (visible) area of the structure, displacements and even deformations are being able to analyze.

Fig. 11 shows the displacements of the Pest side pylon to a best-fit reference plane, thus changes in the cross-sections can be investigated in the unloaded state (left image).

In load cases 2 and 3 the leaning of the pylons can be observed (Fig. 11 images on right).

\section{Cable movements}

The point density of the laserscanned point cloud enables the modeling of the cables and hence the evaluation of their move- 


\section{Aggregated results}

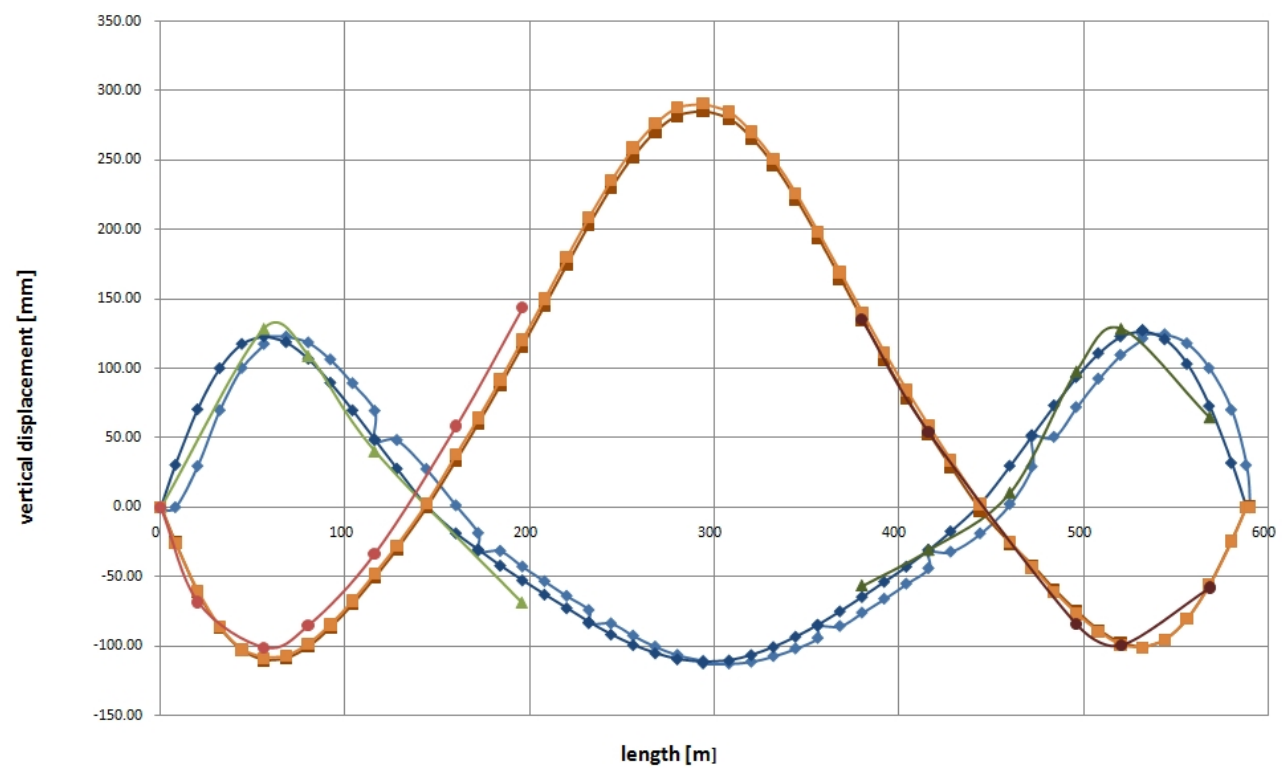

$\rightarrow-2$ leveling_north

$\rightarrow-2$ leveling_south

\pm 2_laserscan_north

\pm 2 _laserscan_south

- -3_leveling_north

- - 3_leveling_south

$\rightarrow-3$ _laserscan_north

$\rightarrow$ 3_laserscan_south

Fig. 10. Comparison of results
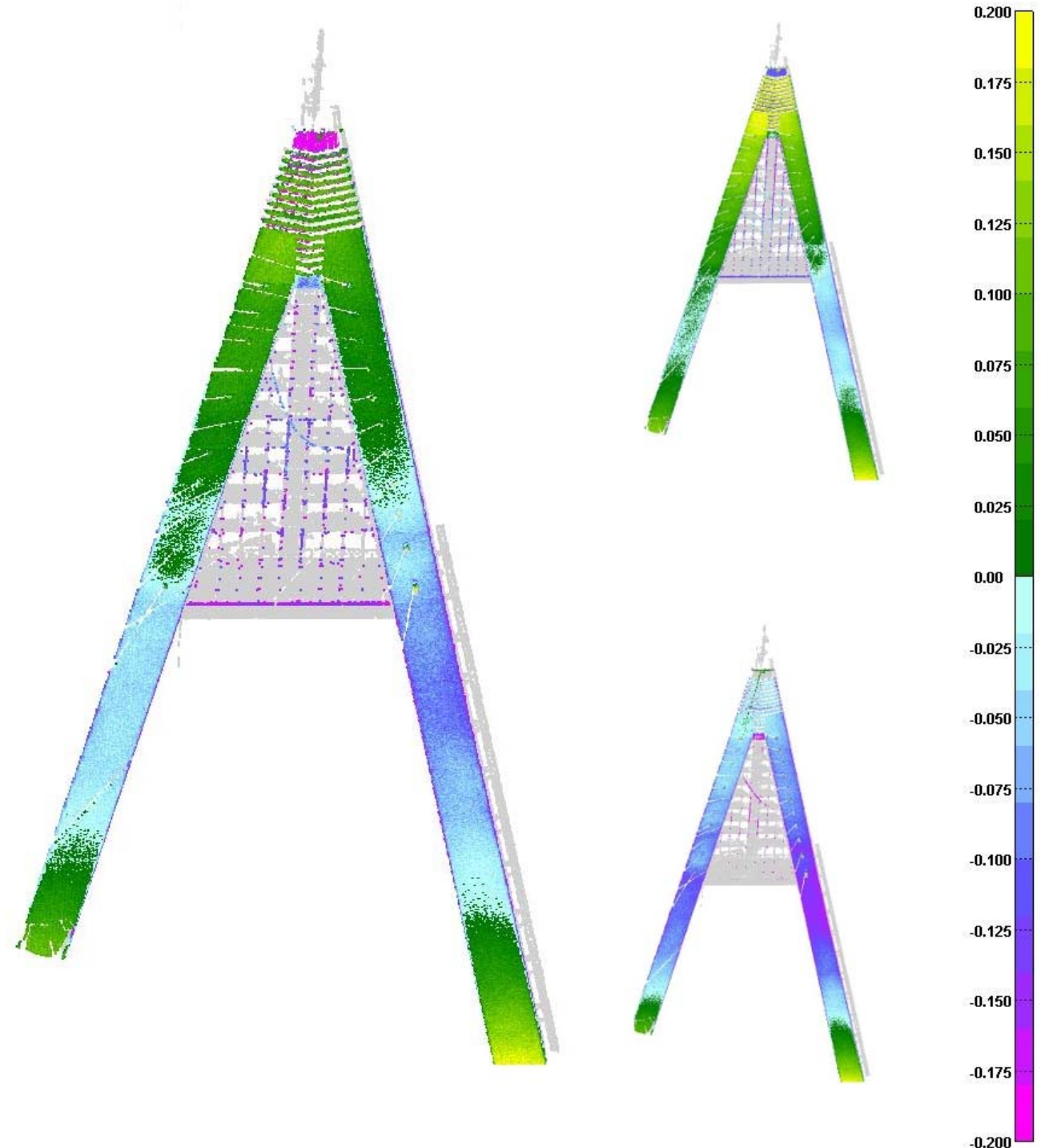

Fig. 11. Pylon's shape, displacements to reference plane [m] 

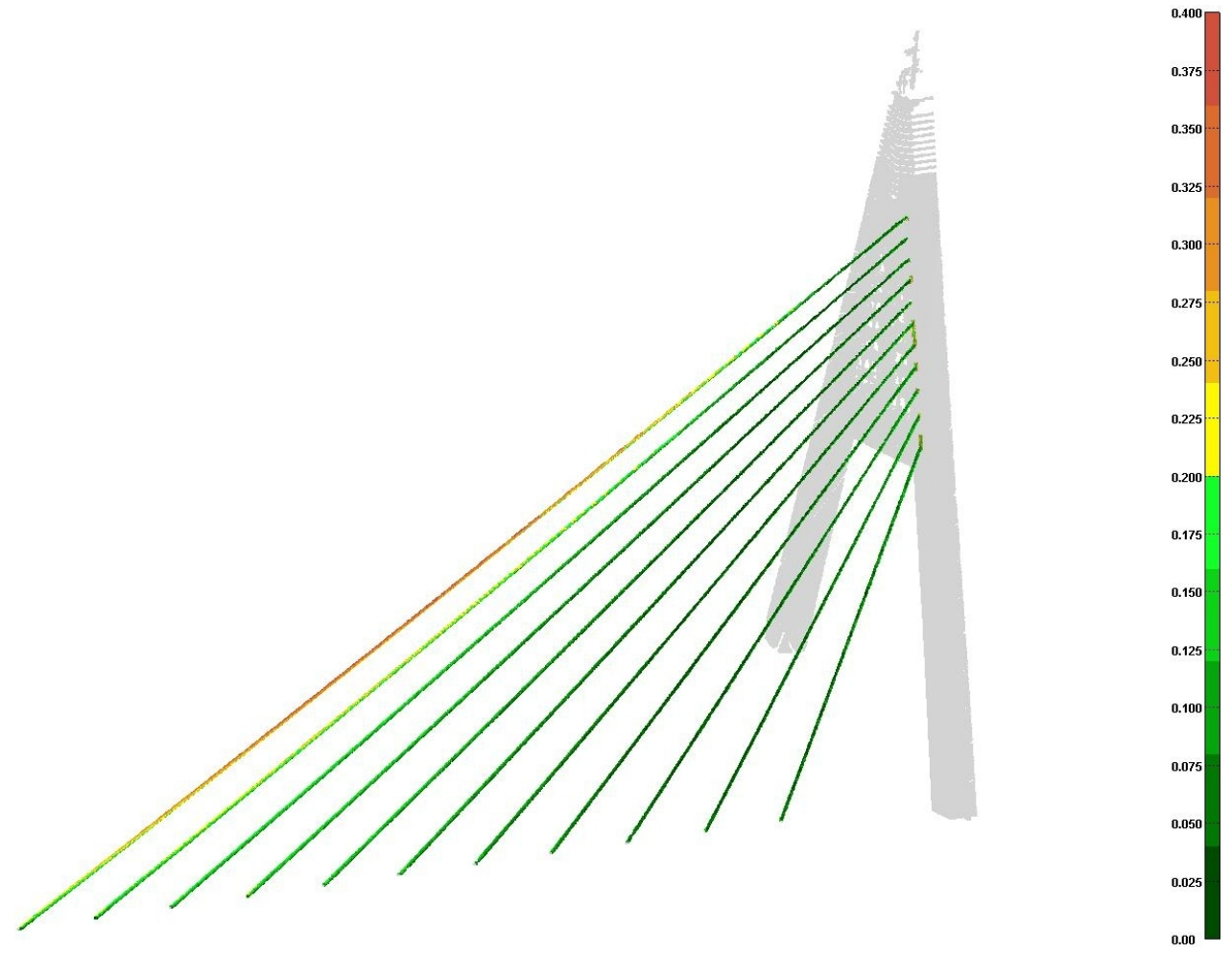

Fig. 12. Cable displacements $[\mathrm{m}]$ in load case 3

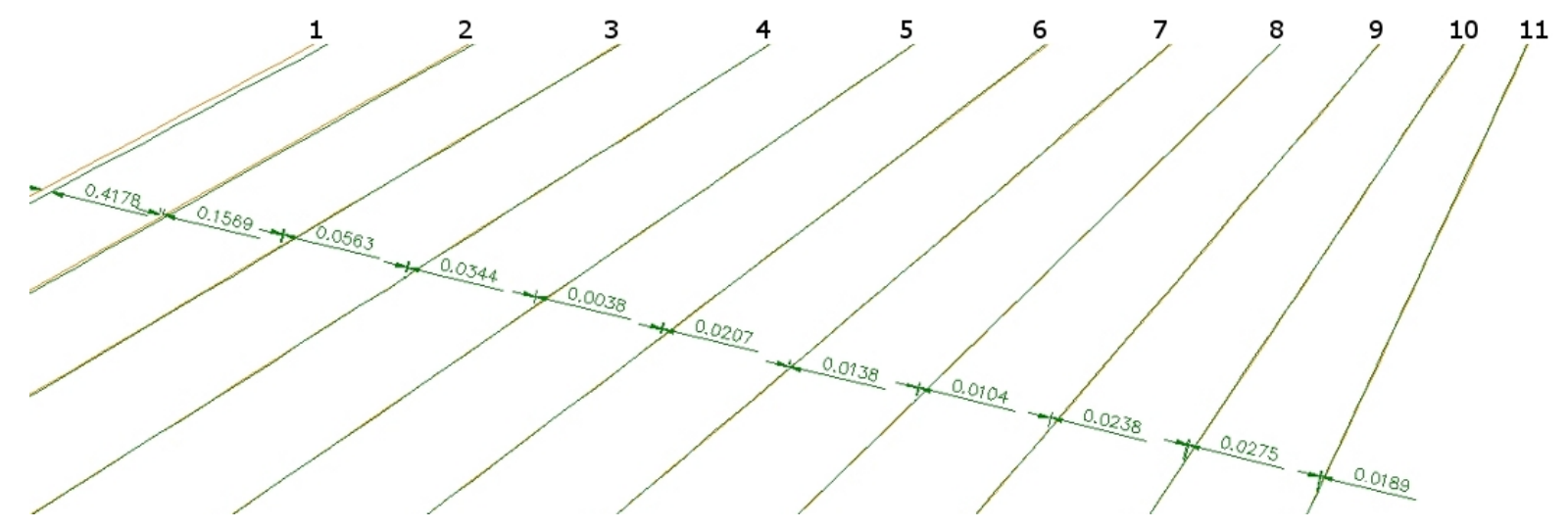

Fig. 13. Cable displacements in load case $2[\mathrm{~m}]$

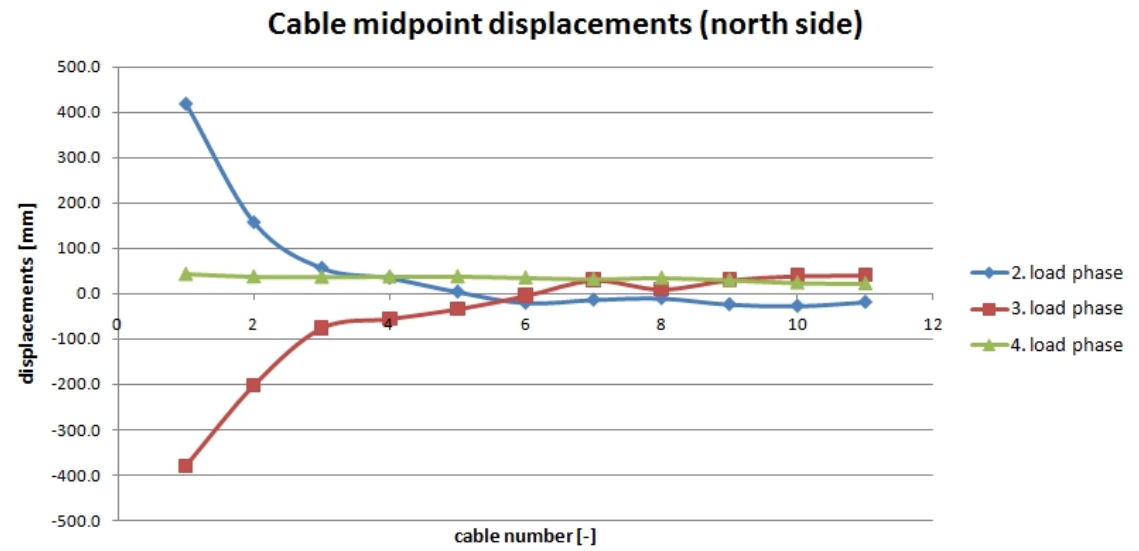

Fig. 14. Cable displacements

ments. Such analyses are not supported by traditional geodetic measurement.

In Fig. 12 the displacements of the northern cables of the
Pest side pylon are shown in shaded representation using the unloaded state as reference. 
It can be clearly seen that the greatest displacements occur at the longest cables. These cables are fixed on and close to the pier supports and are unable to share the load with the deck. Due to the A-shape of the pylons, the cables are not located in a plane therefore in the shaded figure the spatial movements of the cables are represented.

The particular displacement values have been measured on the planar projections of the cables in CAD environment. The reference points have been selected at the middle section of each cable (Fig. 13). The resulted displacements are not the biggest ones, for that, the best fitting curves have to be determined. However, regarding the size of displacements, the manual measurements in the middle sections can be considered as eligible for the current purposes.

The particular cable displacements also can be represented by line curves (Fig. 14).

\section{Conclusion}

Based on the presented results, terrestrial laserscanning proved its potential in deformation and load test measurements. The laserscanned point cloud holds information about the whole visible part of the structure and enables measuring the displacement and deformations during the post-processing, without previously marked, dedicated points.

Analyzing the structure's displacements and distortions in 3D provides reasonable additional information for engineers in the investigation of structural behavior. Our investigations show that analyzing laserscanned data is available even with widely used CAD environment.

The evaluation of the displacements of the cables and pylons clearly show how laserscanning supports such measurements that cannot be achieved by traditional geodetic measurements.

The authors note that laserscanning is to be considered as a useful additional measurement method, since it cannot be evaluated on the same accuracy level as the traditional high-precision equipments.

\section{Acknowledgement}

Authors would like to thank to Burken Ltd. for providing the scanners for the measurement and for the valuable help in data acquisition and processing.

This paper was supported by the János Bolyai Research Scholarship of the Hungarian Academy of Sciences.

\section{References}

1 Lovas T, Berényi A, Barsi Á, Dunai L, A Megyeri híd terhelésvizsgálatának támogatása földi lézerszkenneléssel, Geodézia és Kartográfia LXI (2009), no. 1, 20-26.

2 Lovas T, Barsi Á, Detrekői Á, Dunai L, Csák Z, Polgár A, Berényi A, Kibédy Z, Szőcs K, Terrestrial Laserscanning in Deformation Measurements of Structures, International Archives of Photogrammetry and Remote Sensing XXXVII (2008), 527-531. Part B5.

3 Qiu DW, Wu JG, Terrestrial Laser Scanning for Deformation Monitoring of the Thermal Pipeline Traversed subway Tunnel Engineering, International Archives of Photogrammetry and Remote Sensing XXXVII (2008), 491-494. Part B5.
4 Zogg HM, Ingensand H, Terrestrial Laser Scanning for Deformation Monitoring - Load Tests on the Felsenau Viaduct (CH), International Archives of Photogrammetry and Remote Sensing XXXVII (2008), 555-562. Part B5.

5 Lovas T, Barsi Á, Polgár A, Kibédy Z, Berényi A, Detrekői Á, Dunai L, Potential of Terrestrial Laserscanning Deformation Measurement of Structures, Proc. ASPRS Annual Conference. April 28 - May 2, 2008, pp. 10.

6 Lovas T, Berényi A, Kandra L, Barsi Á, A Megyeri híd terhelésvizsgálatának támogatása földi lézerszkenneléssel, 2008. study.

7 Lovas T, Barsi Á, Polgár A, Kibédy Z, Berényi A, Detrekői Á, Dunai L, A dunaújvárosi Pentele híd terhelésvizsgálatának támogatása földi lézerszkenneléssel, Geodézia és Kartográfia LIX (Budapest), no. 10-11, 32-39.

8 Polgár A, Hídszerkezet terhelésvizsgálatának támogatása földi lézerszkenneléssel, Budapest University of Technology and Economics, 2007. Diploma thesis.

9 Domanovszky S, Tudósítás a Dunaújvárosi Duna-híd acél felszerkezetének építési munkálatairól, Magész Acélszerkezetek IV. évf. (2007), no. 1, 24-42. Magyar Acélszerkezeti szövetség.

10 Horváth A, A tervezó a híd beúsztatásáról, VÉ-KA XXXVI évf. (2007), no. 1, 10-13. Hídépítők melléklet.

11 Csák Z, Acél keretszerkezet deformációmérése lézerszkenneléssel, 2007. Diploma thesis.

12 Lovas T, Barsi Á, Polgár A, A Dunaújvárosi Duna-híd terhelésvizsgálatának támogatása földi lézerszkenneléssel, 2007. study.

13 Kovács E, Tárgyrekonstrukció lézerszkennelés alkalmazásával, Budapest University of Technology and Economics, 2006. Diploma thesis.

14 Maksó M, Mérnöki szerkezetek deformációjának meghatározása földi lézerszkenneléssel, Budapest University of Technology and Economics, 2006. Diploma thesis.

15 Demir N, Bayram B, Alkis Z, Helvaci C, Etin I, Vögtle T, Ringle K, Steinle E, Laser Scanning for Terrestrial Photogrammetry, Alternative system Or Combined With Traditional System?, International Archives of Photogrammetry and Remote Sensing XXXV (2004), 193-197. part B5.

16 Detrekői Á, Joó I (eds.), Deformation measurements, Akadémia kiadó, Budapest, 1983.

17 available at www. laservision.hu 